\title{
Globus sensation due to a metastasis of a malignant melanoma
}

\author{
Charlotte Bultynck $\odot 1,{ }^{1,2}$ Gregory Clement, ${ }^{2}$ Paul Lambert, ${ }^{2}$ Joke Patou ${ }^{2}$
}

${ }^{1}$ Otorhinolaryngology, University Hospital Ghent, Gent, Belgium ${ }^{2}$ Otorhinolaryngology, AZ Damiaan Oostende, Oostende, Belgium

\section{Correspondence to}

Dr Charlotte Bultynck; charlotte.bultynck@ugent.be

Accepted 5 April 2021

\section{DESCRIPTION}

A 70-year-old woman presented at the Ear Nose Throat department with a globus sensation since 3 months.

In the medical history, we withheld an atypical melanocytic lesion with a Breslow thickness of $1.5 \mathrm{~mm}$, assessed after an excision biopsy of a skin lesion on the left buttock in 2016. A therapeutic broader re-excision and an inguinal sentinel lymph node procedure were performed. The anatomopathological examination indicated a skin fragment with ulceration, without residual tumour in the cutting surfaces. There was one positive sentinel lymph node, with a diameter of $2.8 \mathrm{~cm}$. There was no melanoma extending beyond the lymph node capsule. After multidisciplinary consultation, it was decided to perform a left inguinal lymph node dissection. Left inguinal lymph node dissection revealed two lymph nodes free from tumour, confirmed by immunohistochemistry. This cutaneous malignant melanoma could be classified as T2bN1aMx.

Examination of the oral cavity and the neck was unremarkable. By conducting a flexible nasolaryngoscopy, an oval sessile circumscribed mass on the body and the laryngeal surface of the epiglottis was clearly visible. (figure 1) No other abnormality was seen within the upper aerodigestive tract.

A direct laryngoscopy under general anaesthesia for biopsy of the mass on the epiglottis was planned to differentiate between cystic, granulomatous, infectious, neoplastic or manifestations of a systemic disease. ${ }^{12}$

Anatomopathological examination showed overlying epithelium without atypia. Underlying, the corium was massively tumour occupied by rather atypical cells arranged in a noncohesive pattern.

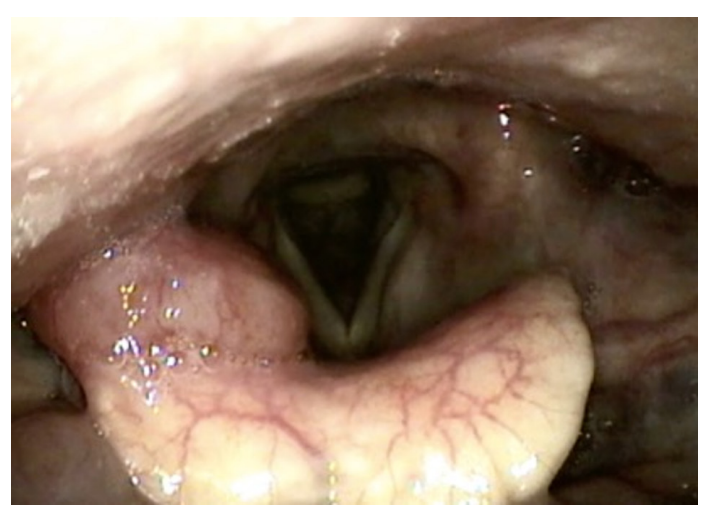

Figure 1 An oval sessile circumscribed mass on the body and the laryngeal surface of the epiglottis.

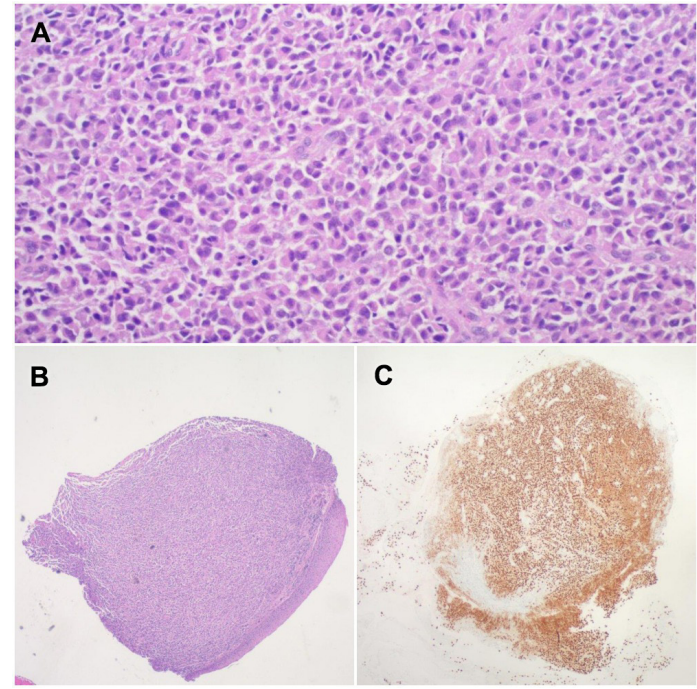

Figure 2 (A) H\&E, 20x illustrating atypical cells arranged in a non-cohesive pattern. The cells carry significant nuclear variability. (B) H\&E $4 \times$ illustrating overlying normal squamous epithelium without atypia. Underlying, the corium is massively tumour occupied by rather atypical cells arranged in a non-cohesive pattern. (C) SOX-10×4 illustrating the SOX-10 expression In the tumorous population (The tumour expressed furthermore HMB45, Melan A and PNL2 and was negative for the lymphoid markers CD45, CD20, CD138.).

They carried significant nuclear variability. Focally there was tumour necrosis. In additional immunohistochemistry studies, the tumour population in the SRY-related HMG-box 10 (SOX10) expressed Human Melanoma Black 45 (HMB45), MelanA and Melanoma Associated Antigen (PNL2) and was negative for the lymphoid markers CD45, CD20,

\section{Learning points}

- It is crucial to perform a thorough flexible nasolaryngoscopy in a patient with globus symptoms.

- For differential diagnosis, the medical history of a patient with an epiglottic mass is very important and a direct laryngoscopy under general anaesthesia for biopsy of the mass should be performed.

- Since the poor prognosis in malignant melanoma metastatic to the larynx, clinicians must use a multidisciplinary approach to provide functional benefit and to maintain quality of life without excessive toxicity. 
CD138 and the short chain Kappa-Lambda (figure 2). There was also no expression for the Pankeratin. The patron had the features of a metastatic localisation of a malignant melanoma. Additionally, no v-raf murine sarcoma viral oncogene homolog B1 (BRAF) mutation was detected with the Idylla test.

CT scan showed a nodular thickening of the epiglottis on the right side.

When the patient heard that the epiglottic mass was a metastasis of a melanoma, she felt very despondent given the poor prognosis she already knew. Given the fact that patients with malignant melanoma metastatic to the larynx have limited survival, treatment is palliative and clinicians must use treatment strategies that provide functional benefit so as to maintain quality of life without excessive toxicity. This requires a multidisciplinary approach. ${ }^{3}$ After a reflection period and after consulting the medical oncologist and the general practitioner, the patient requested euthanasia. Euthanasia was performed later, according to the patient's wishes.
Contributors I declare that all authors contributed to this work. JP and CB saw the patient clinically together. Subsequently, it was planned to write a case report. CB started writing the article. JP, GC, and PL reviewed the article thoroughly and made the necessary changes to the full text.

Funding The authors have not declared a specific grant for this research from any funding agency in the public, commercial or not-for-profit sectors.

Competing interests None declared.

Patient consent for publication Obtained.

Provenance and peer review Not commissioned; externally peer reviewed.

\section{ORCID iD}

Charlotte Bultynck http://orcid.org/0000-0002-0481-2896

\section{REFERENCES}

1 Kumar S, Mathew J, Al-Abri R, et al. Laryngeal mass. Oman Med J 2011;26:293-4.

2 Tresley J, Saraf-Lavi E, Kryvenko O, et al. Epiglottic masses identified on CT imaging: a case report and review of the broad differential diagnosis. Neuroradiol $J$ 2015:28:347-53.

3 Lanson BG, Sanfilippo N, Wang B, et al. Malignant melanoma metastatic to the larynx: treatment and functional outcome. Curr Oncol 2010;17:127-32.

Copyright 2021 BMJ Publishing Group. All rights reserved. For permission to reuse any of this content visit https://www.bmj.com/company/products-services/rights-and-licensing/permissions/

BMJ Case Report Fellows may re-use this article for personal use and teaching without any further permission.

Become a Fellow of BMJ Case Reports today and you can:

- Submit as many cases as you like

- Enjoy fast sympathetic peer review and rapid publication of accepted articles

- Access all the published articles

- Re-use any of the published material for personal use and teaching without further permission

Customer Service

If you have any further queries about your subscription, please contact our customer services team on +44 (0) 2071111105 or via email at support@bmj.com.

Visit casereports.bmj.com for more articles like this and to become a Fellow 